\title{
Vindicación de la historia y la cultura democráticas en las biografías del cine español (2000-2010)
}

\author{
José Luis SÁNChez NoriegA \\ Universidad Complutense de Madrid \\ noriega@ghis.ucm.es
}

Recibido:07/03/2012

Aceptado: 05/07/2012

\section{RESUMEN}

En el clima social y político de reivindicación de la resistencia antifranquista y de investigación de asesinatos en torno a la guerra civil conocido como "memoria histórica" el cine español abunda en el ciclo de cine histórico para llevar a cabo una interpretación de la Historia de España a través de biografías de personajes públicos. Junto a líderes políticos (Azaña, Líster, Blas Infante) y resistentes antifranquistas (Caracremada, Puig Antich, Solé Tura) hay espías (Garbo), líderes latinoamericanos (Allende, Pinochet, Che Guevara) y personas comunes protagonistas de sucesos de trascendencia para la ética pública (Ramón Sampedro). Estas biografías sirven para dar a conocer y homenajear a figuras admiradas, pero también para una reflexión e interpretación sobre el pasado -en interacción con el presente- y para apostar por valores de cultura democrática.

Palabras clave: cine biográfico, franquismo, guerra civil, metacinematografía, ficción y no ficción, anarquismo, Franco, Che Guevara.

\section{Vindication of History and Democratic Culture in Spanish Biopics (2000-2010)}

\begin{abstract}
Within the social and political context of the so called "Historic Memory", which implies a vindication of antifrancoist resistance and investigation of murders during the Civil War, Spanish cinema turns to a series of historical films in order to make an interpretation of the History of Spain through biographies of prominent personalities. Together with political leaders (Azaña, Líster, Blas Infante) and antifrancoist fighters (Caracremada, Puig Antich, Solé Tura), there are secret agents (Garbo), Latin American leaders (Allende, Pinochet, Che Guevara) and ordinary people who become protagonists of events that have a great impact in public ethics. These biopics pay tribute and make these admired figures known, but they also make a reflection and an interpretation of the past-in interaction with the present- and at the same time they clearly support democratic values.
\end{abstract}

Key words: Biopic, francoism, Spanish Civil War, metacinematography, fiction and non fiction, anarchism, Franco, Che Guevara.

Sumario: 1. El acceso al conocimiento histórico a través del biopic. 2. Memoria de la República y la Guerra Civil. 3. Entre la utopía anarquista y la resistencia democrática. 4. El esperpento del Pardo y protagonistas del (anti)franquismo. 5. Líderes de la izquierda latinoamericana. 6. Apologías de la tolerancia. 7. Conclusiones. 8. Bibliografía. 


\section{El acceso al conocimiento histórico a través del biopic}

El presente trabajo se enmarca en un proyecto de investigación ${ }^{1}$ e, inicialmente, trataba de establecer cuál ha sido el discurso del cine español reciente sobre la historia inmediata, cómo se ha construido el imaginario cinematográfico sobre diversas épocas y sucesos del siglo XX. El interés de la cuestión es doble: en primer lugar por la existencia de hibridaciones y estilos audiovisuales que rompen los formatos tradicionales de documental y cine de ficción, con lo que se abunda en el nudo gordiano del citado proyecto; en segundo lugar, al hilo del clima de revisión del franquismo y la consideración de que la transición política cerró en falso algunas heridas, clima del que emana la declaración por las Cortes del Año de la Memoria Histórica (2006) y la posterior ley de la Memoria Histórica (2007), tiene lugar un nuevo ciclo de cine de revisión histórica tras la filmografía de reescritura del pasado habida entre 1976 y $1984^{2}$ y que vuelve sobre episodios y personajes poco conocidos, con evidente propósito reivindicativo que refleja conflictos del presente. Al realizar una primera aproximación al tema, con la búsqueda de los títulos más representativos de lo que convencionalmente podemos llamar cine histórico $^{3}$, tanto ficción como no ficción, sobresalió un dato inadvertido hasta ese momento: la existencia de películas centradas en un personaje real, es decir, un ciclo específico de cine biográfico compuesto por unas 60 cintas, una cifra de suficiente entidad como para ser tenida en cuenta, esto es, como para dedicarle una atención específica.

Un acercamiento a este ciclo permite observar unas líneas mucho más precisas, con intereses más concretos que se pueden agrupar en: a) personajes histórico-legendarios pertenecientes a un pasado más remoto como Hipatia, santa Teresa de Ávila, El Cid, Isabel la Católica, los Borgia, Cervantes, Lope de Vega y El Greco; b) creadores e intelectuales de la Edad de Plata de la cultura española: García Lorca, Salvador Dalí, Luis Buñuel, María Moliner y Óscar Domínguez; c) políticos republicanos, agitadores, revolucionarios y resistentes antifranquistas: Francesc Macià, Blas Infante, Manuel Azaña, Enrique Líster, Felipe Sandoval, Caracremada, Durruti, Lucio Urtubia, Garbo, Jesús de Galíndez, Puig Antich, Yoyes y Solé Tura; d) músicos

1 Nuevas tendencias del paradigma ficción/no ficción en el discurso audiovisual español (2000-2010) (Ministerio de Ciencia e Innovación, CSO2009-07089).

2 Alentado, en parte, por la política de TVE de promover obras literarias de calidad, muchas de las cuales recrean épocas históricas. Principalmente nos referimos a documentales como La ciudad quemada (La ciutat cremada, Antoni Ribas, 1976), La vieja memoria (Jaime Camino, 1977), Raza, el espíritu de Franco (Gonzalo Herralde, 1977), El proceso de Burgos (Imanol Uribe, 1979) y Dolores (J.L. García Sánchez y Andrés Linares, 1980); a las ficciones ambientadas en la República y la Guerra Civil Las largas vacaciones del 36 (Jaime Camino, 1976), Retrato de familia (Antonio Giménez-Rico, 1976), Soldados (Alfonso Ungría, 1978) o Las bicicletas son para el verano (Jaime Chávarri, 1983). La óptica nacionalista de Companys, procès a Catalunya (Josep M. Forn, 1979), la adaptación de la saga La plaça del Diamant (Francesc Betriu, 1982), ;Victoria! (Antoni Ribas, 1982); y el cine vasco de Imanol Uribe sobre ETA -El proceso de Burgos (1979) y La fuga de Segovia (1981)- y filmes como Sabino Arana (Pedro de la Sota, 1980), Akelarre (Pedro Olea, 1983) o Fuego eterno (José Ángel Rebolledo, 1985). Obras sobre el asesinato de Carrero Blanco: Operación Ogro (Gillo Pontecorvo, 1979) y Comando Txikia / Muerte de un presidente (José Luis Madrid, 1976), etc. Véase en Sánchez Noriega (2004a) la entrada "Guerra Civil española".

3 Una panorámica de síntesis sobre las relaciones cine e historia se encuentra en De Pablo (2001); por nuestra parte, en Sánchez Noriega (2004b) hemos desarrollado una categorización sobre el valor historiográfico de distintos tipos de audiovisuales. 
y artistas populares contemporáneos: Lola Flores, Camarón, Enrique Morente, Sara Montiel y Montserrat Caballé; y e) figuras de la historia latinoamericana reciente: Che Guevara, Salvador Allende y Augusto Pinochet.

De todo este conjunto de biografías fílmicas hemos seleccionado las dedicadas a personajes del siglo XX con una trayectoria política a fin de comprobar el segundo de los objetivos señalados más arriba: la existencia de una revisión del franquismo y sus aledaños (antecedentes y consecuentes) en el cine español actual. A las dificultades para establecer el valor historiográfico del cine (documental y argumental) y su fidelidad histórica, o la capacidad de una ficción audiovisual que reconstruye, recrea y hasta imagina detalles, para proporcionar un conocimiento medianamente riguroso sobre sucesos históricos se suma el formato específico de la biografía fílmica o biopic. Ello implica, en primer lugar, discutir el valor de la biografía literaria que, a su vez puede ser un híbrido entre el ensayo biográfico y la novela, y su legitimidad -afirmada y negada en distintas épocas y autores-para el conocimiento científico de la Historia.

El estatuto historiográfico de la biografía ha sido puesto en cuestión, mediado el siglo pasado, desde posiciones de una concepción positivista de la tarea de interpretación de la Historia, particularmente desde la escuela de los Annales y, ya en los años sesenta y setenta, desde el estructuralismo "antihumanista" que privilegia lo colectivo y las estructuras impersonales, y entiende que el devenir de la Historia responde más a cambios políticos, ideologías hegemónicas, procesos económicos, identidades nacionales o factores sociales que a determinaciones de vidas individuales por más relevantes que hayan sido. En todo caso, se entiende que esas vidas responderían a esquemas o estereotipos y los sujetos serían meros actores sociales intercambiables por otros que desarrollarían un rol similar en función de procesos que se sobreponen a cualquier singularidad individual.

Este rechazo tuvo como consecuencia un notable descenso de biografías, tal como en 1975 constataba Carlos Seco Serrano (1989) en su artículo "La biografía como género historiográfico", con el resultado de un empobrecimiento en la aspiración a una "historia íntegra" o "historia total"; y, tras anotar como explicación la ligereza y escasa calidad del género biográfico en los últimos tiempos, este reputado historiador aboga por una biografía científica que, superando la mera semblanza, lleve a cabo una documentación exhaustiva, tenga en cuenta los testimonios literarios coetáneos y se proponga conocer "el individuo y su tiempo" desde los cauces del vitalismo orteguiano (el método histórico de las generaciones) y el análisis psicológico.

Seco Serrano y otros muchos autores abundan en la necesidad de equilibrio en la tensión individuo / sociedad y de superación de una situación en que se opone la Historia científica, de datos y procesos, basada en un conocimiento contrastable de lo público y colectivo, a las vidas azarosas y superficiales de los individuos, cuyo conocimiento se refiere a lo particular e íntimo. Esta tensión (individuo / sociedad, privado / público, particular / general) está en la base de cualquier biografía que, de entrada, en cuanto género historiográfico, ha de ser capaz de trascender la anécdota de la vida concreta por lo que se exige una representatividad, de suerte que el valor del individuo para la historiografía radica en su significatividad como miembro del grupo o especie al que pertenece. Por ello una de las fórmulas más defendidas en el género biográfico ha sido la de las vidas ejemplares que retratan a individuos modéli- 
cos por su capacidad para representar los ideales de una época y por su condición de luchadores épicos que lideran transformaciones sociales.

Se ha considerado que la biografía como género se aproximaba más a la creación literaria que a las ciencias históricas a pesar de que, ya desde Leopold von Ranke o Wilhelm Dilthey, se ha valorado el interés de vidas de personas con una dimensión histórica universal; a ello hay que añadir el hecho de que esas vidas individuales historiografiadas poseen elocuencia como para ser comprendidas inmediatamente por el lector, que ve en ellas una experiencia vital más o menos análoga a la suya, inexistente en los ensayos sobre instituciones, procesos económicos, transformaciones sociales... estudiados por la Historia con mayúsculas. En fin,

La idea es recurrir a él [el personaje analizado] como medio de acceder a una realidad histórica más amplia que es la que se intenta conocer, comprender, explicar; realidad de la que él mismo forma parte -sea como actor principal o de reparto, que eso lo dirá la propia investigación- si bien nunca constituyendo monólogo, sino integrándose en un grupo de afinidades comunes que también debemos identificar (estudio prosopográfico $)^{4}$.

La sospecha frente a la biografía como estrategia para el conocimiento histórico se deriva del rechazo a una historia narrativa que privilegia el orden temporal y causal sin fisuras, otorga protagonismo absoluto a personalidades unitarias y se vale de dramatizaciones del devenir existencial de los individuos que resultan manifiestamente reduccionistas o incluso falsificadoras de los hechos. Se viene a decir que en las biografías la naturaleza historiográfica del discurso queda inevitablemente contaminada por la lingüístico-literaria, la novelesca o la dramatúrgica, de lo cual ha de tomar buena nota el historiador riguroso. Como subraya el profesor Morales Moya, que se ha ocupado por extenso de esta cuestión, la biografía participa de las dimensiones semiótica, narratológica, literaria, filosófica, ideológica... de cualquier relato que ha de ser consciente de su perspectiva:

el contenido de la representación no es indiferente a la forma, pues lo propio de ésta es la producción de significados. Con el discurso narrativo el historiador no se limita necesariamente a comunicar, a informar, por cuanto puede intentar emociones, sentimientos o, incluso, impulsar a la acción, debiendo adecuarse la forma a aquello que queremos representar 5 .

Pero ello no deslegitima completamente el género. En un sustancioso capítulo que resume, con brillante síntesis, el estado de la cuestión Isabel Burdiel aboga por el valor de la biografía como fuente para la historia desde la crítica actual a un modelo dominante que olvide o anule las contradicciones, lagunas o disonancias de un discurso racional de trabada coherencia. Apuesta por el microanálisis y una remozada consideración de lo íntimo y particular desde la convicción de que "La Historia no ocurre fuera de cada experiencia individual y la determina, sino que ocurre dentro,

4 VEIGA ALONSO, Xosé Ramón: "Biografía y conocimiento histórico. El caso del conde de Pallarés", Revista de Historia Contemporánea (Universidad del País Vasco), 13-14 (1996), p. 344.

5 MORALES MOYA, Antonio: "Formas narrativas e historiografía española", Ayer 14 (1994), p. 26. 
y ahí es donde alcanza su valor y sentido." ${ }^{\text {; }}$ bien entendido que el individuo no necesita ser representativo de un grupo o clase, por el contrario, ha de ser radicalmente singular y que, lejos del devenir biográfico de lógica férrea protagonizado por un sujeto unitario, se tienen en cuenta las discontinuidades, las identidades múltiples o la evolución llena de contradicciones de cualquier ser humano.

A toda esta problemática, que exige una cautela notable a la hora de establecer el valor historiográfico de la biografía literaria, se añade una práctica de la biografía fílmica - llamada usualmente biopic, acrónimo de biographical picture- tan variada como compleja; un resbaladizo género sobre el que la discusión teórica puede ser interminable y sobre el que proliferan más los estudios prácticos con recopilaciones y catálogos, como el muy interesante de George F. Custen (1992) sobre el cine clásico entre 1927 y 1960, o los análisis de títulos, como el dedicado por Dennis Bingham (2010) a Rembrandt (1936), Ciudadano Kane, Lawrence de Arabia, Nixon, Ed Wood, Malcolm X y Lumumba, entre otras, que las teorizaciones propiamente dichas. En su decisivo ensayo sobre la identidad de los géneros cinematográficos Rick Altman ${ }^{7}$ nos hace ver cómo la configuración de esta clase de películas tiene lugar, en los primeros años del cine sonoro, al hilo de estrategia llamada el "Juego del Productor", basada en la repetición de fórmulas de éxito, con el resultado de que la condición biográfica se subordina, por imperativo industrial, a esquemas narrativos o rutinas de género.

Para lo que aquí nos interesa, es preciso subrayar que, por encima de la fidelidad a los datos, en la construcción de biografías predominan perspectivas como $a$ ) la proyección sobre el pasado de valores o visiones del mundo actuales, $b$ ) la elaboración de una dramaturgia que convierte la vida reflejada en dosificado espectáculo, entretenimiento o aventura, $c$ ) la transformación del sujeto en un personaje legendario provisto de cualidades heroicas o excepcional poder de seducción, o, en definitiva, d) la opción por un cine de género (drama sentimental, comedia romántica, capa y espada, psicodrama, etc.) o por una interpretación libre de la figura del personaje. Es decir, la realidad histórica del sujeto biografiado queda relegada a un segundo plano en beneficio de la pura construcción cinematográfica que hace valer los mecanismos dramatúrgicos y espectaculares propios del cine de género.

\section{Memoria de la República y la Guerra Civil}

Un político andalucista, un presidente republicano, un independentista catalán, un líder comunista y un sacerdote conciliador son las figuras de la República y la guerra reivindicadas por el cine español de estos años. Es evidente el propósito de dar a conocer a los personajes de forma serena, ubicados en el contexto histórico preciso, y hacerlo desde una distancia, subrayada de diversos modos en los textos fílmicos, particularmente con los relatos de doble nivel; esa voluntad de conocimiento lleva implícito el reconocimiento, pues estas biografías constituyen también un homenaje

6 BURDIEL, Isabel: «La dama de blanco: notas sobre la biografía histórica», en BURDIEL, Isabel y PÉREZ LEDESMA, Manuel (coords.), Liberales, agitadores y conspiradores. Biografias heterodoxas del siglo XIX, Espasa-Calpe, Madrid, 2000, pp. 40-41.

7 ALTMAN, Rick: Los géneros cinematográficos, Barcelona, Paidós, 2000, pp. 65-72. 
donde se plasma la admiración hacia los principios éticos, las respuestas a los retos históricos y la trayectoria pública de los personajes (cf. Moral, 2010).

El así nombrado Padre de la Patria Andaluza, Blas Infante Pérez de Vargas (18851936) es objeto de reconocimiento en Una pasión singular (Antonio Gonzalo, 2002), un largometraje biográfico de evidente propósito de didáctica política al mostrar la vida del notario y teórico del andalucismo desde sus últimos días, con la detención por falangistas, las desesperadas gestiones para conseguir su libertad y su ominoso asesinato en una carretera en los primeros días de la Guerra Civil. En esta ficción, la condición de víctima heroica adquirida contra su voluntad por Infante otorga un sentido preciso a su vida, informada por una dimensión teleológica providencial, sintetizada tanto en su dimensión pública como en la privada y en la que destaca la condición integradora y pacifista de su andalucismo. Se pasa por alto el episodio de la -presunta o comprobada, según unas u otras fuentes- conversión al Islam del político $^{8}$. Este filme se ha considerado parte de una llamada trilogía autonómica (Alonso Gutiérrez, 2010) junto a Companys, procès a Catalunya (Josep María Forn, 1979) y A los cuatro vientos (José Antonio Zorrilla, 1987), con al menos un elemento común, pues "los militares aparecen en ellos como guardianes de una España-eterna- que se opone a cambios políticos que signifiquen una mayor autonomía o autogobierno, son fuerzas reaccionarias que se oponen al idealismo progresista que los protagonistas representan" ". Forn vuelve al nacionalismo catalán para recrear la figura del antecesor de Lluís Companys en la Generalitat de Catalunya en El coronel Macià (2006), un homenaje al militar y político catalanista de cuidada ambientación que se centra en el último año de su vida y subraya la dignidad y lucha por la libertad de conciencia de este personaje en el contexto de un ejército punta de lanza de la España reaccionaria; todo ello viene filtrado por la narración de una historiadora irlandesa, testigo excepcional de los hechos.

La ficción de cine en el cine Azaña (Santiago San Miguel, 2008) se inicia con los primeros días de agosto de 1936 y las tensiones del Presidente de la República para frenar el golpe de Estado y evitar la guerra. Se reconstruye en breves secuencias de carácter didáctico precedidas de un rótulo explicativo la actividad del presidente desencuentros con Largo Caballero y otros socialistas, relación con el militar Saravia, estrategia con golpistas, etc.- y en contados flashbacks se ilustra su personalidad con episodios de su carrera política. La narración del episodio de brutalidad policial de Casas Viejas es el único momento en que el relato se decanta por la técnica documental con una voz over sobrepuesta a fotografías de la época. A medida que avanza el relato, la ilusión de la ficción se va agrietando para devenir un relato con dos niveles donde queda patente la autoconciencia de la representación: ello se alcanza mediante a) una voz over, por tanto externa a la diégesis, que explicita el sentido de algunos

\footnotetext{
8 Véase, a modo de ejemplo, el artículo de Gustavo Bueno: "Un musulmán va a ser reconocido en referéndum como 'Padre de la Patria Andaluza'”, El Catoblepas, n 60, febrero 2007, disponible en http://www.nodulo.org/ ec/2007/n060p02.htm (visitado 11-11-2011). También puede consultarse "Blas Infante y el Islam" de Ali Manzano (2-2-2008) en http://www.webislam.com/articulos/32916-blas_infante_y_el_islam.html

9 ALONSO GUTIÉRREZ, Juan Manuel: "Los militares en cinco biopics de la democracia", en Actas del II Congreso Internacional Historia y Cine: la biografía filmica, Universidad Carlos III de Madrid, 2010, disponible en http://e-archivo.uc3m.es/handle/10016/11295
} 
sucesos o conversaciones; $b$ ) la lectura de los diarios de Azaña, mientras se muestra al personajes redactándolos, que establece un punto de vista subjetivo; y $c$ ) la ruptura de la ficción de 1936 con secuencias donde en la actualidad los actores hablan sobre los personajes históricos y comentan los acontecimientos del pasado. La hibridación alcanza su punto culminante cuando el relato fusiona pasado y presente: en primer lugar, con la voz en off de Azaña contando su estancia en Cataluña mientras las imágenes muestran la ciudad en la actualidad, con gentes en las calles y el habitual trasiego ciudadano; y en segundo lugar cuando el actor Jordi Dauder, que encarna al político, evoca la salida de España, el progresivo deterioro físico y, a continuación, lee el testamento y se acerca físicamente al político ya muerto y le coloca las gafas. Es decir, que vemos en el mismo espacio dramático al personaje y al actor duplicados e interactuando, lo que permite, acto seguido, un llamamiento de Azaña por la III República con el que la película culmina su voluntad didáctica de homenaje al político desde un presente que reivindica su memoria y la causa republicana.

Liste, pronunciado Lister (Margarita Ledo Andión, 2007) es una suerte de ensayo biográfico que reconstruye la poliédrica personalidad del cantero gallego nacido en 1907 como Xesús Liste y el general en varios ejércitos y líder comunista muerto en 1994 como Enrique Líster. El rótulo inicial advierte sobre la condición de la pelícu$\mathrm{la}^{10}$, a la que se atribuye una autoría colectiva y en la que se combinan imágenes y audios de archivo de diversas épocas, entrevistas actuales a la esposa, familiares y amigos, cómics animados, fragmentos de cine, conversaciones y celebraciones con cantos de las personas que indagan en la biografía y representaciones teatrales sobre episodios biográficos o sucesos que recrean el contexto histórico. Esta variedad de materiales hace ver el subrayado de la obra en cuanto ensayo que indaga en la personalidad de alguien sobre quien hay equívoco hasta en la primerísima aproximación que es el nombre; ello queda subrayado, en una feliz metáfora, en los créditos iniciales con la composición con tipos de imprenta tradicional del propio título de la película: el espectador ve cómo se elabora a mano el rótulo "Liste, pronunciado Líster" y entiende que lo que viene a continuación no es sino la elaboración de esa trayectoria del niño (Liste) al adulto (Líster).

Como no podía ser de otro modo, en este docudrama, Margarita Ledo indaga en la generación de los viejos comunistas que se vieron deslumbrados en su juventud por la Revolución Soviética, vivieron las aspiraciones de los convulsos años treinta, resistieron a los fascismos en los campos de batalla de Europa, fueron huéspedes del estalinismo, rechazaron la primavera de Praga y hasta conocieron la caída del muro del Berlín y el ocaso de sus organizaciones políticas. A través de los testimonios sobre la guerra civil, el exilio y la supervivencia en los países comunistas, la película hace una profesión de fe revolucionaria al mostrar al grupo de personas (actores, amigos, familiares) que se reúnen literalmente bajo unas banderas para evocar la vida de Líster y compartir su esperanza histórica. La cinta se articula en un relato de doble nivel con el material de archivo, las entrevistas y los datos sobre Líster por un lado, y las

\footnotetext{
10 "Para hacer un filme sobre Líster un grupo de personas repasan materiales, lo evocan, se acercan por primera vez a este niño de aldea que, como en las coplas, llega a general de los ejércitos ruso, polaco y yugoslavo durante la guerra mundial y, con la llamada 'guerra fría', lo encuentran en el Consejo Mundial de la Paz. A lo largo de esta conversación ilimitada, emerge otro modo de mirar a Líster”.
} 
interpretaciones, comentarios, dramatizaciones de sucesos o cantos y otras formas de homenaje hechos desde el presente. En este sentido, hay que subrayar la utilización de Tchapaief, el guerrillero rojo (Chapaiev, Georgi y Sergei Vasiliev, 1934) como alegoría de la propia vida de Líster, al menos en los episodios bélicos, con lo que se viene a ilustrar con una ficción cinematográfica la narración de sucesos históricos ${ }^{11}$. El teatrillo que aparece en varios momentos evita la ilusión de la representación que sumerja al espectador en otra época para, por el contrario, manifestar su condición teatral, casi un happening, en la que unos ciudadanos actuales que sintonizan con Líster se ponen en la piel de sus contemporáneos.

A través de la figura del sacerdote navarro Marino Ayerra (1903-1988), tío de la cineasta Helena Taberna ${ }^{12}$, en el largometraje de ficción La buena nueva (2008), se hace homenaje a esa significativa minoría de católicos que se resisten a bautizar el golpe de Franco como cruzada y denuncian la impunidad criminal de la represión fascista. Destinado en el nudo ferroviario de Alsasua (Alzania, en la ficción) durante la contienda, un pueblo de mayoría socialista y ramalazos anticlericales cuyo anterior párroco acabó enemistado con todos, Ayerra intenta en todo momento la conciliación y ponerse de parte de los pobres, sin forzar confesionalidades ni exigir prácticas religiosas. Obviamente es un adelantado a los postulados de libertad de conciencia y libertad religiosa que aceptará la Iglesia en el concilio Vaticano II. El enfrentamiento con carlistas y falangistas va en aumento y se vuelve insostenible cuando denuncia la represión -36 personas fueron asesinadas y arrojadas a fosas comunes-, trata de proteger a republicanos escondidos y llega a favorecer la huida de un joven que va a ser asesinado. Finalmente no le queda más remedio que emprender el camino del exilio. Por tanto, la biografía de Ayerra se limita a los tres años de la guerra.

No sabemos hasta qué punto la ficción es fiel a los hechos precisos, particularmente en la esfera más personal, como la relación del sacerdote con Margari. Incluso se aprecia la inevitable perspectiva de que todo filme histórico habla tanto del presente como del tiempo pasado al que se refiere, como sucede con los apuntes del párroco sobre la localización de las fosas de los fusilados, que entrega al monaguillo para que quede constancia en el futuro... y que parece responder a la muy vigente exigencia de recuperación de la memoria histórica. El deseo de contraponer la iglesia perseguida frente a la mayoritaria que apoya el golpe fascista es muy evidente en el montaje paralelo de la misa en la plaza del pueblo presidida por los mandos falangistas y requetés y la procesión del cura con las viudas de los represaliados hasta las fosas comunes del monte. La historia de Marino Ayerra filmada por Taberna aborda una perspectiva importante -la función política e ideológica desempeñada por el catolicismo- con la pretensión de completar la verdad con hechos minoritarios pero muy significativos.

11 Este sentido metafórico no existe en otros fragmentos de cine insertados, como las secuencias e Ispanja (Esfir Shub, 1939), Galicia, (Carlos Velo, 1936), Spanish Earth (Joris Ivens, 1937) o Y cuando Lister llegó (Mauro Azcona, 1937), que funcionan como documentales ilustrativos de la guerra.

12 Anteriormente, la directora había realizado sobre esta misma figura histórica el cortometraje Alsasua 1936 (1994) de media hora de duración, protagonizado por Fernando Guillén Cuervo, y el documental de entrevistas en vídeo Recuerdos del 36 en el mismo año. 


\section{Entre la utopía anarquista y la resistencia democrática}

Los personajes del anarquismo español del siglo XX no habían sido muy tratados por nuestro cine, a pesar de su peso evidente en la guerra, su condición visionaria y las vidas aventureras y novelescas de algunos de ellos como Lucio, aspecto este último que da pie a reconstruir las biografías del espía Garbo o del nacionalista vasco Galíndez. La figura de Felipe Sandoval (1886-1939) sirve de hilo conductor para una crónica de los grupos violentos de anarquismo de acción directa a lo largo del primer tercio del siglo XX en El honor de las injurias (Carlos García-Alix, 2007). El título subraya el origen en un espacio madrileño marginal a finales del siglo XIX -el así llamado Barrio de las Injurias, a la altura de la glorieta de Pirámides ${ }^{13}$ - de quien desarrolla una carrera delincuente y se ve poseído por la utopía ácrata y la fiebre revolucionaria de encontrar el paraíso a la sombra de las espadas, convirtiéndose en detestable jefe de la checa del cine Europa durante la guerra. Un manuscrito de 63 páginas redactado por Sandoval, también conocido como Doctor Muñiz, tras ser apresado en 1939 sirve para documentar esta biografía que se ilustra con fotos, imágenes de atestados policiales y otros textos, y fragmentos de archivo, tanto de noticiarios como de ficciones. Apenas hay testimonios escritos, orales o visuales directos, lo que se suple con materiales de carácter general que acaban ensanchando el horizonte del documental para ir más allá de la biografía de Sandoval e indagar en la violencia política y la lucha de clases en la España de Alfonso XIII y la República. En otra trinchera, con los adversarios como verdugos, se ubica otro anarquista, Félix Costa, protagonista del mediometraje Tierra encima (Sergio Morcillo, 2005), que, ya octogenario, rememora la Guerra Civil y el momento en que fue dado por muerto tras el fusilamiento del que escapó en el litoral barcelonés, en los terrenos del final de la Diagonal.

El histórico anarcosindicalista Buenaventura Durruti (1896-1936), beligerante líder de la FAI incómodo para la II República y figura de referencia durante la guerra, es objeto de atención de un largometraje de formato singular, pues se trata de una especie de documental sobre la preparación de una puesta en escena teatral que se basa únicamente en textos escritos. Además de con la utilización de unos rótulos que ponen en relación el tiempo actual contado en semanas y el pasado histórico, indicado con las fechas, Buenaventura Durruti, anarquista (Jean-Louis Comolli y Ginette Lavigne, 2000) se distancia del personaje con dos procedimientos: mediante el narrador interpuesto Chicho Sánchez Ferlosio, que intercala unas canciones con la misma función que los cantares de ciego que llevan de pueblo en pueblo una leyenda, y mediante la compañía de teatro Els Joglars que se encuentra en proceso de creación de una obra dedicada a Durruti, lee textos suyos o sobre él y esboza la representación de episodios concretos de su vida. Esta distancia se explicita en cuanto las escasas imágenes de archivo no son reproducidas sin más, sino que vienen comentadas por

13 Este subrayado viene a explicar la evolución de Sandoval, de delincuente a militante revolucionario. Pío Baroja en Mala hierba (1904), segunda entrega de la trilogía La lucha por la vida, describe así este lugar en un momento en que coincide con la infancia de Sandoval: "El barrio de las Injurias se despoblaba, iban saliendo sus habitantes hacia Madrid...Era gente astrosa: algunos, traperos; otros, mendigos; otros, muertos de hambre; casi todos de facha repulsiva. Era una basura humana, envuelta en guiñapos, entumecida por el frío y la humedad, la que vomitaba aquel barrio infecto. Era la herpe, la lacra, el color amarillo de la terciana, el párpado retraído, todos los estigmas de la enfermedad y la miseria". 
el director del grupo, Albert Boadella, quien indica las dificultades de su trabajo de creación de una obra de teatro; a ello contribuye también el hecho de que los fragmentos en que se representan episodios de la vida de Durruti tiene una puesta en escena teatral, no cinematográfica, y en algunos momentos se interrumpe lo que es un ensayo para corregir y perfeccionar su dramaturgia. Más que el devenir existencial o la biografía pública del personaje, se hace hincapié en su ideología, militancia y compromiso. Por todo ello, la película no es ni un documental ni una ficción sobre Durruti, sino un documental sobre una puesta en escena teatral, de un tipo de teatro manifiestamente ideológico, casi un happening, en torno a la figura histórica, vista desde el presente, del líder anarcosindicalista.

Otro personaje marginal imbuido de la utopía anarquista es el protagonista de $\mathrm{Lu}$ cio (Aitor Arregi y José María Goenaga Balerdi, 2007), un navarro nacido en Cascante en 1931 y huido a París en 1954, donde su espíritu rebelde descubre la ideología ácrata de la mano del mítico Quico Sabaté. Vivió desde dentro el fenómeno de mayo del 68, apoyó al incipiente régimen de Castro (aunque su idea de provocar la bancarrota de Estados Unidos inundando el mundo con dólares falsos fabricados en Cuba fue desdeñada por Che Guevara), participó en toda clase de actividades antifranquistas, atracó bancos para las causas revolucionarias, ayudó a cientos de exiliados proporcionándoles documentación falsa, a organizaciones como ETA político-militar, Tupamaros, el Frente Polisario, los Panteras Negras, las Brigadas Rojas... e incluso planeó secuestrar al nazi Klaus Barbie. En la década de los setenta consiguió estafar al First National Bank (Citibank en la actualidad) entre 15 y 20 millones de dólares de la época, falsificando cheques de viaje de American Express, que sirvieron para financiar a movimientos libertarios de diversos países. Para reconstruir esa vida el documental se vale de testimonios directos, incluido el propio Lucio Urtubia, su esposa y su hermana, además de una veintena de personajes. Hay breves fragmentos de ficción con actores que dramatizan episodios concretos de esa increíble vida.

Menos interés tiene La mujer del anarquista (Peter Sehr y Marie Noëlle, 2008), una ficción de base biográfica excesivamente sesgada hacia los componentes melodramáticos, que reconstruye la historia de una pareja republicana (Justo y Manuela) a partir de los testimonios de su hija Paloma, a su vez, madre de la codirectora de la película. Se cuentan los últimos meses de la guerra, con el padre arengando a las tropas republicanas desde la radio, la posterior huida a Francia -con las miserias de rehacer de nuevo la vida- y la actividad resistente del ácrata Justo, que planea un atentado contra Franco.

La memoria de la resistencia antifranquista tiene una peculiarísima biografía en el documental de creación Caracremada (Lluís Galter, 2010), un largometraje próximo al cine experimental, carente de toda música y casi por completo de diálogo, que utiliza mecanismos de sinécdoque visual y temporal al mostrar detalles de una realidad más amplia y dejar en manos del espectador la reconstrucción de la totalidad. Ello tiene lugar tanto en el espacio, con planos muy próximos y planos de detalle, como en el tiempo, con fuertes elipsis de segmentos de la historia y una narración fragmentada, llegando a un resultado donde la diferencia entre ficción y no ficción se diluye y queda relegada a un segundo plano en beneficio de la búsqueda de la experimentación virtual de sentimientos o vivencias como el miedo, el frío, la soledad o el hambre 
que atenazan al protagonista, Ramón Vila Capdevila (1908-1963), también llamado Pasos Largos, el último maquis anarquista que continuó su lucha particular después de que la CNT decretase en 1951 el fin de la resistencia armada al franquismo. El relato ilustra de forma impresionista la preparación de atentados contra torres de alta tensión, la búsqueda de comida, el miedo en el refugio, la ayuda de una joven o la vigilancia mutua con la Guardia Civil, todo ello en un clima de silencio obligado que revela tanto la exigencia de la clandestinidad como el clima de falta de libertad.

La propia Remedios Montero oficia de narradora de Memorias de una guerrillera (Pau Vergara, 2007), el documental que reconstruye su trayectoria desde su adolescencia en que apoya a los resistentes antifranquistas echados al monte, su detención y los años de cárcel, la huida a París, la militancia comunista en el exilio, el encuentro en Praga con el maquis del que se enamoró... hasta el regreso agridulce tras la muerte de Franco a un país devenido extraño a pesar de haberlo amado mucho.

Una muy particular biografía es el documental Garbo. El hombre que salvó al mundo (Edmon Roch, 2009) que reconstruye la vida de Juan Pujol García (19121988), un barcelonés que durante la II Guerra Mundial desempeña labores de espionaje tanto para los británicos como para el III Reich y logra engañar a los nazis haciéndoles creer que la ofensiva aliada sería en el Paso de Calais y que el desembarco de Normandía era simplemente una maniobra de distracción; por estos trabajos logra ser condecorado simultáneamente con la Cruz de Hierro nazi y con la Orden del Imperio Británico. En esta reconstrucción la línea de separación entre la realidad y la ficción -que, en este caso, es tanto como decir entre la verdad y la leyenda- resulta particularmente frágil, tanto por la dificultad objetiva para esclarecer hechos sobre un tipo que hace de la simulación y el engaño su material de trabajo y oculta su identidad bajo personalidades de ficción, como por la articulación de imágenes de archivo procedentes de noticiarios y de películas de ficción que sirven de ilustración, pero también de legitimación, para el discurso fílmico.

El enunciador de Garbo se vale de cinco entrevistados a través de los cuales se va reconstruyendo esa vida: el novelista y ensayista especializado en temas de espionaje Nigel West (Rupert Allason) que logra localizar a Garbo en el 40 aniversario del desembarco de Normandía, el experto en inteligencia militar Mark Seaman, el periodista de investigación Xavier Vinader, el psiquiatra Stan Vranckx, conocedor de las técnicas nazis de manipulación de la opinión pública, y la espía norteamericana Aline Griffith, condesa de Romanones. Los entrevistados no son identificados de inmediato, lo que contribuye a que sus testimonios, en algunos momentos, parezcan falsos o interesados si se los contrapone a fragmentos de películas de ficción ${ }^{14}$, insertados en el documental con la pretensión de ilustrarlos, pero también con valor probatorio, pues en varios momentos un diálogo de una película de ficción legitima un argumento

14 Hay fragmentos de Patton (Franklin J. Schaffner, 1970), El día más largo (The Longest Day, Ken Annakin, 1962), Operación Cicerón (5 Fingers, Joseph L. Mankiewicz, 1952), Nuestro hombre en La Habana (Our Man in Havana, Carol Reed, 1959), El último mensaje del Sr. Moto (Mr. Moto's Last Warning, Norman Foster, 1939), El extraño (The Stranger, Orson Welles, 1946), Pimpernel Smith (Leslie Howard, 1941), Invisible Agent (Edwin L. Marin, 1942), The Secret Code (Spencer Gordon Bennet, 1942), British Intelligence (Terry O. Morse, 1940) y Mata Hari (George Fitzmaurice, 1931), protagonizada por Greta Garbo, cuyas virtudes interpretativas sirven para el sobrenombre otorgado a Juan Pujol. 
sobre la vida de Garbo. También hay un inserto de cine de animación que simula ser material de archivo. Estos fragmentos de películas logran -al menos en los casos de Operación Cicerón y Nuestro hombre en La Habana- el inesperado efecto de ver en los personajes unas representaciones o proyecciones de Juan Pujol; de este modo, la ficción inserta en el documental sitúa a Garbo como un personaje propio del imaginario cinematográfico, subrayando que una peripecia vital como la suya, tan de ficción, solo es comprensible si se la ubica en las historias legendarias del cine de ficción. La sospecha frente a la realidad queda arraigada en el espectador quien nunca tiene certeza acerca de la naturaleza del material audiovisual; pero mucho menos sobre los hechos protagonizados por Juan Pujol, un sujeto que desde Lisboa simula estar en la capital londinense y adopta varias personalidades y se inventa confidentes; acabada la guerra desaparece y creen que ha muerto en Angola en 1949, pero es localizado en Venezuela treinta años después donde ejerce como profesor de inglés en la Shell y ha fundado una familia, para sorpresa de la esposa e hijos que dejara en Barcelona tras la guerra civil.

La azarosa historia del jurista antifranquista y nacionalista vasco Jesús de Galíndez (1915-1956) ha sido novelada por Manuel Vázquez Montalbán en Galíndez (1990), además de dar lugar a varias monografías. Exiliado en la República Dominicana tras nuestra guerra, se traslada a Nueva York en 1946, donde es profesor de la Universidad de Columbia y escribe una tesis doctoral sobre la dictadura de Trujillo, lo que le supone el secuestro por agentes dominicanos y, probablemente, la tortura y asesinato en 1956. Parece que la CIA y el FBI, con quienes había colaborado antes del reconocimiento norteamericano del régimen de Franco, estuvieron implicados; no se ha logrado esclarecer la verdad sobre esa desaparición. El largometraje Galíndez (2002) dirigido por Ana Díez y producido por Ángel Amigo es un documental de entrevistas que lleva a cabo una cuidadosa reconstrucción de esa vida convulsa desde los años de estudiante de Derecho en Madrid hasta su secuestro; apenas hay imágenes de archivo y la voz narradora es muy escasa en beneficio de los variadísimos testimonios, incluido el del novelista Vázquez Montalbán.

En la novela de éste se inspira el largo de ficción El misterio Galíndez (Gerardo Herrero, 2003) que establece un relato de doble nivel, conducido por el personaje de Muriel, una estudiante norteamericana que investiga en 1988 lo sucedido en 1956. La narración va contraponiendo ese presente de los años ochenta, con la relación de Muriel con un novio español y sus viajes a Santo Domingo y Nueva York, donde un agente norteamericano mueve todas las fichas posibles para evitar que Muriel siga investigando, influyendo en el profesor que la dirige y en el organismo que la beca, lo que consigue finalmente con su asesinato. En el pasado hay una reconstrucción dramatizada con las diversas hipótesis de la suerte de Galíndez tras su secuestro. Esta propuesta de ficción resulta menos informativa y mucho más superficial para el conocimiento del nacionalista vasco que el documental de Ana Díez; a cambio, con el desarrollo de una trama de ficción en tiempo presente y la hipótesis de que el gobierno de Estados Unidos es responsable de la muerte de Galíndez, viene a mostrar cómo ese episodio no está enterrado definitivamente, sino que tiene consecuencias en la actualidad. Con ello la película trasciende el caso Galíndez y adquiere una dimensión más universal al reflexionar sobre los mecanismos del poder para silenciar las 
opiniones discordantes y denunciar la prepotencia norteamericana que subordina el respeto a los derechos humanos a sus intereses políticos o económicos.

\section{El esperpento del Pardo y protagonistas del (anti)franquismo}

Por razones más que evidentes, la guerra y la dictadura de Franco son objeto central del cine histórico español desde la restauración democrática. El cine más reciente se ha ocupado de la última etapa del franquismo y la transición con episodios (Puig Antich, Heinz Chez, Yoyes) y personajes con trayectorias públicas muy definidas por la relación con el autócrata, sea de afinidad (Fraga) o de oposición (Carrillo, Solé Tura $)^{15}$. La figura de Franco cuenta con una filmografía bastante amplia, a pesar de que no se haya rodado ninguna biografía o relato que alcance el conjunto de su trayectoria vital. Además de la hagiográfica Franco, ese hombre (José Luis Sáez de Heredia, 1964), ya en democracia hay obras con episodios concretos como el inicio de la Guerra Civil (Dragon Rapide, Jaime Camino, 1986), la ficcionalización en clave de humor de Espérame en el cielo (Antonio Mercero, 1988) o la alegoría de talante esperpéntico Madregilda (Francisco Regueiro, 1993) ${ }^{16}$.

Albert Boadella y Els Joglars, en lo que ha sido, estrictamente, el único proyecto cinematográfico de la compañía teatral de amplia trayectoria, llevan a cabo en ;Buen viaje, Excelencia! (2003) una gran caricatura, a modo de retrato granguiñolesco, de la figura de Franco. El relato se ubica en un presente que abarca los dos últimos años de la vida del autócrata, desde el atentado a Carrero Blanco a su fallecimiento, con fragmentos de recuerdos y fantasías, insertos en blanco y negro, desde el punto de vista subjetivo de los personajes; se articula en una dialógica entre la élite que rodea a Franco (espacio de El Pardo) y diversos tipos representativos de la sociedad del tardofranquismo (espacio de un bar popular), de manera que se contrapone el delirio en que se sume aquella élite en los años postreros de la dictadura con la España real que se sitúa en otra perspectiva, con grupos de oposición frontal ante los cuales el búnker representa bien poco. En las antípodas de cualquier voluntad documental, el relato subraya de diversos modos su condición de representación, de parodia teatral y hasta de esperpento, como revelan la gestualidad y modulación de la voz en la composición del personaje de Franco y de bastantes otros, la repetición de actores en diversos papeles o el cameo como ciego de Albert Boadella pregonando la suerte en el momento del atentado a Carrero, además de las pesadillas que vive el general.

15 Han sido las miniseries de televisión quienes han tomado el relevo del cine en la elaboración de ficciones audiovisuales con la pretensión de crónica; en varios casos, la biografía se limita a una época muy precisa o la reconstrucción de un momento determinado, como sucede con los dos últimos jefes de Estado españoles en 20-N: los últimos días de Franco (Roberto Bodegas, 2008, A3), y 23-F, el día más difícil del Rey (Silvia Quer, 2009, TVE), 23-F, historia de una traición (Antonio Recio, 2009, A3) y Una bala para el Rey (Pablo Barrera, 2009, A3); o se hace un retrato centrado en los pocos años de vida pública: Adolfo Suárez, el presidente (Sergio Cabrera, 2010, A3).

16 Resulta muy completa la aproximación del número doble de Archivos de la Filmoteca, núm. $42-43$ (octubre 2002-febrero 2003) a la iconografía de Franco en todo tipo de representaciones; en esos dos volúmenes destacan los trabajos sobre Franco, ese hombre (Ángel Quintana), Espérame en el cielo (Nancy Berthier) y Madregilda (Sonia García López). 
El texto fílmico emplea diversas texturas de las imágenes en función de su naturaleza: blanco y negro con celuloide deteriorado para las imágenes de archivo, tanto las reales como las reconstruidas; color realista para las imágenes de la realidad en tiempo presente; e imágenes con distorsiones ópticas y cromáticas para las fantasías. Se da la circunstancia, aparentemente contradictoria, de que se utilizan estrategias propias de un documento como las imágenes de archivo (reales o no) para contenidos que manifiestamente son de ficción en una operación de (falsa) legitimación que, en definitiva, viene a formar parte del juego escénico de todo el conjunto de la representación.

La enunciación juega con elementos reales para amplificarlos en una distorsión esperpéntica y conseguir mayor elocuencia por su condición ridícula. Gracias a las hipérboles empleadas se permite la licencia de ensamblar imágenes de archivo en blanco y negro con desarrollos de ficción utilizados como falsas imágenes de archivo, como la entrevista con Hitler en Hendaya o escenas de pesca en el Azor. Más que biográfica o historiográfica -lo que conlleva voluntad de transmisión de conocimiento- la pretensión última de este largometraje es la realización del retrato de un personaje ya conocido, un retrato alternativo al muy idealizado y repetido a lo largo de décadas por el régimen. Se trata de mostrar las telarañas de la trastienda o el revés de cartón piedra en una operación desmitificadora de la figura del "Caudillo por la gracia de Dios" que, obviamente, da por supuesta la familiaridad del espectador con la imagen oficial. De hecho, sin un mínimo conocimiento del contexto histórico sería incomprensible esta caricatura, sobre todo de la época precisa de los dos años reflejados (diciembre de 1973-noviembre de 1975) con la mostración de actitudes frente al régimen (grupos de oposición, nostálgicos del búnker y la desafección de la mayor parte de la ciudadanía), el protagonismo del marqués de Villaverde y la superstición (brazo incorrupto de santa Teresa y manto de la Virgen del Pilar) durante la enfermedad de Franco, las incertidumbres de la familia y la corte de El Pardo, las tensiones y diferencias entre los ministros, etc.

Esa manufactura caricaturesca se alcanza por la vía de $a$ ) la ficcionalización o desarrollo dramatúrgico de hechos reales, $b$ ) la inclusión de personajes o sucesos inventados y $c$ ) por los sueños o delirios que tienen lugar en la mente del dictador. En el primer grupo están hechos y detalles como el citado magnicidio, episodios de la guerra y escenas de la vida pública, inauguración de un pantano, la declaración del estado de excepción, el "enterado" de los últimos fusilados de ETA y Frap de septiembre de 1975, el encarnizamiento terapéutico que sufre en su agonía, la afición de Carmen Polo por las joyas o de Franco al cine, las manipulaciones de Villaverde en la agonía, los fragmentos de discursos y muletillas que evoca Franco en momentos inesperados, la instrucción militar como ejercicio terapéutico, etc.

Al segundo grupo pertenecen elementos claramente inventados como la figura de la psiquiatra Müller, hija de un nazi protegido por Franco y llamada para curarle con la oposición de Villaverde, las comidas de El Pardo amenizadas con música militar por una banda que deambula por los jardines o la visita a un pueblo desértico y en ruinas con el séquito simulando un recibimiento grandioso con el telón de fondo sonoro del pasodoble Suspiros de España, en una de las secuencias más inspiradas de toda la cinta. No son añadidos caprichosos ni digresiones destinadas a incrementar el humor 
del relato, sino auténticas profundizaciones con la pretensión de hacer más elocuente el trasfondo ideológico, los hábitos y costumbres, y la vida cotidiana de la camarilla del poder de El Pardo. En la misma perspectiva están las fantasías/pesadillas que vive el general: evocación de episodios bélicos (con la crueldad que supone celebrar con galletas de chocolate un fusilamiento sumarial), la satisfacción de la eficacia de la tortura, la traslación de un proceso infeccioso al terreno de la lucha militar, la expulsión de Carmen Polo del palacio, el pánico a la destrucción de su obra tras su muerte, la voladura de la cruz del Valle de los Caídos, etc.

El díptico Últimos testigos: Fraga Iribane - Carrillo comunista (2008) está formado por dos largometrajes, sendas entrevistas realizadas por separado y con distintos directores en las que se hace un repaso a la trayectoria política y al conjunto de la historia de España que les ha tocado vivir. En el primero, dirigido por el documentalista y director de fotografía José Luis López Linares, Manuel Fraga hace un repaso de los años de la República y su papel en la dictadura, expresa sus opiniones sobre los nacionalismos y no aporta muchas novedades, fuera de su rechazo a ir de segundo de abordo en el gobierno comandado por Adolfo Suárez tras la muerte de Franco. El titulado Carrillo comunista, de Manuel Martín Cuenca, es una entrevista con el antiguo líder del Partido Comunista de España, que, tras evocar su dimisión como secretario general a raíz de la pérdida de votos, se retrotrae a la vida política de la República, con la radicalización entre una posible dictadura fascista y una deseada revolución y a partir de ahí va hilando su trayectoria política en el largo exilio. Se hacen preguntas muy precisas sobre la responsabilidad de Carrillo en los asesinatos durante la guerra y sobre los aspectos más cuestionables del socialismo real, como el estalinismo, el aplastamiento de la primavera de Praga, la expulsión de Semprún y Claudín. Hay un apoyo importante de imágenes de archivo y el resultado es una contribución de primera mano a la historia española del siglo XX desde la memoria personal de un protagonista de primera fila.

En buena medida homenaje, pero también -como el mismo título indica- memoria y reivindicación del compromiso antifranquista y de lucha por las libertades, el espléndido documental Bucarest, la memoria perdida (Albert Solé, 2008) ${ }^{17}$ surge a raíz de que al militante comunista, "padre" de la Constitución y posterior ministro socialista de Cultura, Jordi Solé Tura (1930-2009) le fuera diagnosticada la enfermedad de Alzheimer. Su hijo pone en marcha un trabajo de reconstrucción de la biografía familiar, política y académica que, tan inevitable como afortunadamente, constituye una aportación a la historia de la oposición antifranquista, a la vida de los exiliados y a las disensiones en el seno del Partido Comunista que alcanzaron un punto álgido con las expulsiones de Fernando Claudín y Jorge Semprún en 1964. Basado en testimonios de personas que han conocido al protagonista, éste aparece como una sombra de quien fue, con su incapacidad para recordar. El trabajo presenta una fuerte carga emotiva al estar narrado en primera persona con la voz en off de Albert Solé, que conduce el relato indagando en sus orígenes a través de la reconstrucción de la vida de su padre.

17 Disponible para el visionado en http://www.rtve.es/alacarta/videos/los-documentales-de-culturales/ documentales-culturales-bucarest-memoria-perdida/489821/ 
En marzo de 1974 son condenados a muerte y ejecutados con garrote vil el militante anarquista Salvador Puig Antich y el considerado apátrida Heinz Chez. Ambos fueron acusados de matar a agentes del orden y juzgados por tribunales militares sin muchas garantías legales. Todo parece indicar que el régimen de Franco respondía con dureza al asesinato de Carrero Blanco de un par de meses atrás, sobre todo en el caso de Heinz Chez que, carente de cualquier militancia política, fue utilizado como chivo expiatorio. Con un tratamiento de ficción muy cinematográfico, Salvador (Puig Antinch) (Manuel Huerga, 2006) narra la creación de un grupo del MIL (Movimiento Ibérico de Liberación), dedicado a atracar bancos para financiar las luchas obreras y la resistencia antifranquista, y el paso a la clandestinidad de su protagonista. Detenido tras la muerte de un policía en un tiroteo, Salvador narra en primera persona a su abogado episodios de su pasado: la rebeldía de un grupo de estudiantes antifranquistas, la relación con su novia, las primeras acciones, la huida a Francia...; posteriormente hay un fragmento sobre la investigación de la policía narrado por su novia y más tarde, ya en tiempo presente y con la perspectiva omnisciente, se cuenta pormenorizadamente todo el proceso judicial, la condena a muerte y la ejecución. La instancia narrativa muestra una distancia con los hechos reconstruidos y la condición subjetiva de un relato que subraya en su forma (textura de las imágenes, tratamiento fotográfico, montaje, planificación) su carácter cinematográfico, aún más evidente en una segunda parte en tiempo presente que maneja mecanismos de género como la intriga y la participación emocional del espectador en todo el desarrollo del proceso judicial hasta un desenlace en que, inopinadamente, un funcionario de prisiones protesta por la ejecución. No faltan las pincelas descriptivas de la conculcación de derechos humanos en el tardofranquismo, pero Salvador se aparta del documento o de la búsqueda de conocimiento para situarse en una perspectiva de convencida denuncia del ajusticiamiento de un joven antifranquista: no en vano, además de contar con subvención del "Programa per al Memorial Democràtic" de la Generalitat de Catalunya, un rótulo inicial advierte que en los últimos años de la dictadura "La represión del régimen provoca miles de prisioneros políticos y decenas de estudiantes y trabajadores muertos"

Al supuesto polaco Heinz Chez -en realidad, es el alemán del Este Georg Michael Welzel- está dedicado La muerte de nadie (El enigma de Heinz Chez) (Joan Dolç, 2004), un documental de entrevistas que va reconstruyendo cuidadosamente la evolución de Welzel desde la cárcel que sufre en la Alemania comunista, los intentos de huida, las relaciones familiares, el deambular por Europa y la desgraciada llegada a la España de la dictadura agonizante en una existencia fatal marcada por un posible trastorno psíquico. Este trabajo documental -sólo se permite la licencia de unos breves fragmentos que dramatizan el momento de la ejecución con garrote vil- tiene la virtud añadida de mostrar la falta de libertades, la brutalidad policial y la conculcación de los derechos humanos tanto en la República Democrática Alemana como en el régimen de Franco. También queda subrayada la relevancia posterior del suceso con la obra de teatro La torna de Els Joglars que, ya en democracia, le supuso a su director un procesamiento militar y el exilio.

La represión política de los coletazos del franquismo durante la Transición ocupa un lugar destacado en Llach. La revolta permanent (Lluís Danès, 2006) que bos- 
queja la figura del cantautor catalán a partir de los sucesos del 3 de marzo de 1976 en Vitoria que inspiran su Campanades a mort, una de las canciones emblemáticas de la época, y realizado con ocasión de un recital de Llach que conmemora el $30^{\circ}$ aniversario de aquella matanza. A través de testimonios de sindicalistas, trabajadores y familiares se hace crónica de la protesta de los empleados de Forjas Alavesas desalojados de forma brutal por la policía de una iglesia donde estaban encerrados con el resultado de una masacre con cinco personas asesinadas y numerosos heridos. Los diversos testimonios de los protagonistas y, sobre todo, las grabaciones de la policía logran una recreación muy emocionante del suceso histórico, sobre el que también opina el entonces ministro Rodolfo Martín Villa, además de incluirse fragmentos de la rueda de prensa de Fraga Iribarne dos días después de los hechos. Lejos de cualquier proceso mitologizante, de Lluís Llach se aportan sus opiniones a través del tiempo gracias a las imágenes de archivo de diversas entrevistas en televisión, lo que proporciona una visión caleidoscópica de enorme interés: la identidad del músico viene reconstruida por el espectador mediante la dialéctica de declaraciones, variadas y diversas en temas y perspectivas, realizadas a lo largo de los años.

Entre el tardofranquismo y la democracia consolidada transcurre la biografía fílmica de la militante etarra Dolores González Cataraín (1954-1986), conocida como Yoyes y filmada por Helena Taberna en Yoyes (2000). Como se sabe, lo llamativo de este caso es que Yoyes es asesinada por la propia ETA, que considera una mala propaganda que alguien deje la organización y se reincorpore a una vida normalizada. El relato va articulando diversos episodios del pasado desde 1973 con un presente que viene a condensar los dos años transcurridos entre su regreso de México tras haber abandonado ETA en 1984, la residencia en París con su hijo y su marido, la vuelta de estos dos al País Vasco y más tarde de ella misma, tras entrevistarse con un dirigente etarra que le ofrece continuar en la organización, aunque no en la estructura militar. La ficción se toma algunas libertades, lo que advierte un rótulo inicial ${ }^{18}$, que no afectan a lo que inevitablemente es un relato esquemático en el que se tienen que resumir sucesos, conversaciones, posiciones políticas, contexto histórico... que viene a mantener la explicación más convincente y extendida acerca de la trayectoria de Yoyes y de la decisión de asesinarla; únicamente se le puede reprochar que establece cierta equiparación entre ETA y los GAL, cuando ello no es posible ni en tiempo ni en número de víctimas.

\section{Líderes de la izquierda latinoamericana}

La figura de Ernesto "Che" Guevara (1928-1967) forma parte de la mitología revolucionaria del siglo XX y su imagen con profusión de carteles y pintadas que desarrollan la célebre foto de Alberto Korda de 1960 encabeza la iconografía pública de estas décadas. Al poco de su muerte se filman dos largometrajes de ficción: la producción italiana El 'Che' Guevara (Paolo Heusch, 1968) con Paco Rabal como protagonista

18 "Una historia inspirada en hechos reales. Algunas personas, lugares, situaciones y hechos han sido cambiados". 
y la norteamericana Che! (Richard Fleischer, 1969), con Omar Sharif en el mismo papel de Che. Han de pasar siete lustros para que, fuera de algunos documentales y productos para televisión, y de la presencia episódica en el musical Evita (Alan Parker, 1996), el cine vuelva a centrarse en el médico argentino, lo que sucede con la poco conocida cinta estadounidense Che Guevara (Josh Evans, 2005), con el español Eduardo Noriega como Che y el italiano Enrico Lo Verso como Fidel, el documental cubano Che Guevara donde jamás se lo imaginan (Manuel Pérez, 2004), la coproducción de Argentina, Cuba y España Che, un hombre nuevo (Tristán Bauer, 2010) y, sobre todo, con Diarios de motocicleta (Walter Salles, 2004) y la obra estrenada en dos partes Che, el argentino y Che: guerrilla (Steven Soderbergh, 2008) con el puertorriqueño Benicio del Toro encabezando el reparto. Se da la circunstancia de que estas cuatro últimas películas -con distinto grado de participación española en la producción- están basadas en los textos escritos por el propio Guevara, lo que hace de ellas una suerte de biografía personal o de autobiografía filmada por otros: Diarios de motocicleta se basa en Diarios de motocicleta: notas de un viaje por América Latina que recoge el periplo de Che y Alberto Granado en 1952; y, según indican los créditos de los largometrajes el guión de Che, el argentino se inspira en Recuerdos de la guerra revolucionaria en Cuba (1963) y el guión de Che: guerrilla (2008) figura como adaptación del Diario del Che en Bolivia (1968, publicado en 1994).

La película Diarios de motocicleta contiene mucha ficción en cuanto pone en pie una dramatización a partir de notas sueltas y observaciones muy heterogéneas redactadas a lo largo de los siete meses primeros meses de 1952 en que Guevara recorre Argentina, Chile, Perú, Colombia y Venezuela, con una escala en Miami en el regreso. El relato contiene fragmentos de las cartas de Ernesto a su madre-incluidas en los diarios- y, al final, una reproducción de las (falsas) fotografías que Che hizo a lo largo del periplo como testimonio de sus preocupaciones, lo que refuerza su condición autobiográfica; con su dosis de aventura, locura juvenil o ritual de iniciación a la edad adulta, queda patente la condición transformadora del viaje para el sujeto -elemento, por otra parte, muy presente en toda la literatura y la filmografía de este género- lo que queda ratificado con las palabras finales que pronuncia en off al final del relato: "Ese vagar sin rumbo por nuestra mayúscula América me ha cambiado más de lo que creía. Yo ya no soy yo, por lo menos no soy el mismo yo interior". Esta transformación viene dada por la observación de las desigualdades sociales, la pobreza, la enfermedad y la ignorancia en distintos contextos latinoamericanos; sobre todo hay insistencia en las enfermedades, lo que no es de extrañar, dada la condición de bioquímico de Alberto Granado ${ }^{19}$ y de estudiante de Medicina de Guevara. Algunos episodios de relaciones con mujeres y la propia elección de Gael García Bernal hacen de Che una figura con un sesgo seductor, entrañable, con cierta fragilidad..., lo que no es de extrañar para quien posteriormente será un líder social.

El díptico - en realidad, una película, dividida por razones comerciales- de Steven Soderbergh Che, el argentino y Che: guerrilla recrea, respectivamente, la trayectoria de militancia revolucionaria de Ernesto Guevara en Cuba y Bolivia. En la primera

19 Este compañero de Che vuelve a realizar gran parte del viaje a sus 88 años al colaborar en el documental italo-argentino De viaje con el Che Guevara (In viaggio con il Che, Gianni Miná, 2004) que es un particular making off de la película de Walter Salles. 
entrega el relato se articula en dos tiempos: uno que va aproximadamente de 1956 a 1959 y que muestra desde los primeros pasos del Movimiento 26 de Julio en Sierra Maestra hasta la caída del régimen de Batista y la toma de poder por el grupo liderado por Fidel Castro. El desarrollo de estos hechos, filmados en color, ocupa la mayoría del metraje y el retrato que se presenta de un ilusionado, generoso y optimista Guevara combina la lucha guerrillera con su actividad como médico, tanto con los campesinos de las aldeas de montaña como con sus compañeros heridos, sucesos de la vida cotidiana (búsqueda y preparación de comida) y la episodios de la moral del grupo o de traiciones y desfallecimientos. Se pone de relieve el interés de Che Guevara en que los militantes aprendan a leer y a escribir, lo que exige como condición para participar de la revolución.

El segundo nivel del relato, con imágenes en blanco y negro, es una suerte de falso documental con imágenes de Guevara en Estados Unidos que contienen una larga entrevista periodística, encuentros con dirigentes norteamericanos y su discurso en la sede de Naciones Unidas de 1964. Este relato se inserta en el primero mediante breves fragmentos que vienen a explicar desde un tiempo posterior la ideología, el espíritu revolucionario y los análisis políticos de Guevara sobre el imperialismo norteamericano, las desigualdades sociales o la fraternidad de los países de América Latina. Con ello la película adquiere un talante didáctico, propio del modelo de biografía como vida ejemplar, pues se proporciona a los sucesos representados en la ficción un sentido último, se le da a la biografía una lectura a la vez fiel a los textos del propio Che y a cómo la historia posterior ha venido interpretando esa vida. $\mathrm{Ni}$ esta estrategia, ni otra equivalente, ha sido considerada en la continuación Che: guerrilla que reconstruye el último año de la vida de Che, entre noviembre de 1966 y octubre de 1967, cuando entra clandestinamente en Bolivia y organiza una guerrilla con el propósito de derribar la dictadura del general Barrientos. Esta segunda parte de la biografía revolucionaria muestra a un Guevara cansado, aislado y en manifiesta decadencia, no en vano viene del fracaso de nueve meses de lucha guerrillera en Congo; su grupo apenas tiene apoyo en los campesinos y bien pronto se muestra que las acciones armadas no llegan a resultados. Soderbergh filma una coherente segunda parte de la biografía en clave antiépica, humanizando al personaje y siendo fiel a la realidad por encima del personaje en que, ya en ese momento, se ha convertido Che.

El documental Che, un hombre nuevo resulta mucho más completo e independiente de los escritos de Guevara que las ficciones anteriores, lo que hace de ella probablemente la película más valiosa en cuanto biografía, esto es, en orden del conocimiento del personaje histórico, lo que incluye su sensibilidad poética y literaria. Maneja los textos de Che, sus fotografías y diverso material de archivo - con algunas aportaciones inéditas, como el propio documental subraya mostrando el momento preciso en que se accede a ellas- pero renuncia a entrevistar a personajes que lo conocieron; el relato verbal se apoya en un narrador externo -el propio narrador cinemático, Tristán Bauer, con lo que queda subrayado el compromiso del enunciador con el enunciado- que relata esa vida acompañándose de textos de Guevara en bastantes ocasiones, la mayor parte de ellas con una finalidad testimonial de condensar en citas literales el sentido de algunos sucesos o perspectivas, pero siempre desde la visión personal del cineasta. El valor del documental es mayor si atendemos a la honradez y 
coherencia de su planteamiento: coexiste la imprescindible empatía con el personaje con un retrato de su idealismo y con datos sobre sus roces con la Revolución cubana o su distanciamiento de la Unión Soviética.

El cineasta chileno Patricio Guzmán es uno de los puntales del llamado "cine de Allende" que a principios de los setenta tuvo su primavera en el país andino, bien pronto abortada por el golpe de Pinochet. Además de una lección de documental, el tríptico La batalla de Chile (1977-1980) es un compendio de cine comprometido y elocuente en su reconstrucción de la presidencia de Allende y el golpe militar. En El caso Pinochet (2001) reconstruye el proceso judicial iniciado en España por genocidio que le supuso al dictador su arresto en Londres en 1998. En Salvador Allende (2004) lleva a cabo una rigurosa biografía del médico y presidente Salvador Allende (1908-1973) mediante un delicado trabajo de archivo que ordena el tiempo, y proporciona datos importantes del contexto histórico; el cineasta se erige en narrador en primera persona, también como testigo de la época.

Guzmán extrae de sus inagotables archivos documentales un retrato del hombre como político (sin desdeñar matices de la vida familiar), de su trayectoria hasta llegar al poder a través de las urnas, previa conquista de los intereses de las clases más desfavorecidas, a las que dedicó su vida. Sus biógrafos no se ponen de acuerdo en la naturaleza de su doctrina: que si era marxista, leninista, o sólo un insólito revolucionario... En cualquier caso pretendió marcar un hito sin precedentes en la transición a un socialismo democrático de una manera pacífica, con el respaldo de la voluntad popular. La ilusión por la utopía, las ganas de construir una nación justa social y democráticamente se palpa en cada una de las secuencias de archivo registradas por Guzmán, que se conjugan con los testimonios de personas implicadas en aquellos acontecimientos, como el del embajador de la época de EE.UU. en Santiago, que no titubea a la hora de atribuir a su Estado una responsabilidad inmediata (incluido el asesinato por parte de la CIA de un alto cargo militar próximo a Allende) en el golpe del 11 de septiembre. Otros testigos sin embargo se muestran huidizos cuando se les pide volver la vista treinta años atrás, lo que enlaza con la denuncia que de la amnesia política chilena hizo Guzmán en La memoria obstinada (1997).

\section{Apologías de la tolerancia}

Las biografías de otros personajes históricos -históricos en cuanto realmente existentes no por su protagonismo en la Historia- carecen de interés en sí mismas por la escasa o nula relevancia pública de estos individuos, por lo que tampoco hay actividad público-política reseñable. Pero la biografía fílmica posee una innegable trascendencia ideológica en el momento en que se difunde la película; es decir, que la dimensión política se encuentra en el presente del texto fílmico y no en el pasado del personaje histórico, sea cual sea la distancia temporal entre uno y otro. Nos referimos a tres películas de finales de esta década del cine español de comienzo del siglo XXI que convergen en su crítica a la vertiente fundamentalista del catolicismo hispano y a su actividad encaminada a la limitación o supresión de derechos ciudadanos o de leyes recientes (ley 13/2005 que permite el matrimonio de personas del mismo sexo y 
de la ley de aborto de 2010), las reacciones frente a una eventual ley de eutanasia del PSOE, las denuncias de eutanasia del Hospital Severo Ochoa de Leganés (Madrid) y a casos concretos de personas que han demandado ayuda para terminar con su vida de forma legal; y los ataques a la asignatura de Educación para la Ciudadanía y los Derechos Humanos (2006), a la que se aprecia como una herramienta de manipulación de las conciencias de los niños. En efecto, más que elaborar una biografía al uso, en el caso de Ágora, Mar adentro, Camino y Al final de la escapada las figuras protagonistas son retratadas en cuanto paradigmas para la difusión de valores como la tolerancia, la preeminencia de lo humano como criterio para cualquier norma moral o la crítica del fundamentalismo religioso.

En Ágora (2009) Alejandro Amenábar se inspira en la vida de la filósofa neoplatónica Hypatia (c. 355-416) para un llamamiento a la tolerancia y la convivencia entre las distintas creencias religiosas, al conocimiento racional y el progreso de las ciencias, a la independencia del intelectual y a la igualdad de mujeres y hombres. Hypatia es una estudiosa de astronomía y matemáticas, seguidora de Plotino, que tuvo en Alejandría una escuela para una élite de discípulos cristianos y paganos, entre ellos su seguidor el obispo Sinesio de Cirene, y terminó sus días linchada por un grupo cristiano, en un clima de enfrentamiento entre diferentes facciones cristianas y de hostilidad hacia el paganismo. Personaje sobre el que existe una abundante literatura -ensayos, novelas, biografías y múltiples referencias desde antiguo- ha sido vista como "mártir de la ciencia" y figura protofeminista. Dada la lejanía del personaje histórico y las escasas certezas sobre su vida la película lleva a cabo más una aproximación a una época, unos sucesos y unas preocupaciones, que a lo que puede ser la figura concreta de Hypatia, que queda bastante desdibujada incluso en su afán de conocimiento astronómico, además de las siempre recurrentes relaciones sentimentales/sexuales con el esclavo Davo y el pretendiente Orestes. Al margen de los valores cinematográficos, la recepción ha puesto de relieve la condición de alegoría de este relato que fustiga el integrismo religioso del presente, tanto islámico como católico. El mismo Alejandro Amenábar había dirigido Mar adentro (2004), que reconstruye la penosa lucha de Ramón Sampedro, un hombre que queda teatrapléjico a raíz de un accidente y pide la eutanasia en diversas instancias sin encontrar más solución que la complicidad de un grupo de amigos que le facilitan una medicación con la que termina su penosa existencia; este caso, condenado reiteradamente por la Iglesia católica, tuvo cierta continuación en el de Inmaculada Echevarría, paciente de distrofia muscular progresiva quien, a diferencia, de Sampedro, necesitaba ventilación mecánica para vivir; se le permitió la desconexión en 2007, aunque las presiones al hospital católico de san Juan de Dios en que se encontraba, llevaron a su traslado en el último momento a un hospital público ${ }^{20}$. Tres años después el Parlamento de Andalucía aprueba la ley de Muerte Digna que, aunque no innova, clarifica y refuerza los derechos del paciente para aceptar o rechazar un tratamiento médico.

\footnotetext{
20 Las autoridades andaluzas que emitieron un dictamen favorable fueron denunciadas por el partido ultraderechista Alternativa Española. Para este y otros casos de debate en torno a la "muerte digna" en ese momento véase el artículo de Pablo SIMÓN-LORDA e Inés María BARRIO-CANTALEJO: "El caso de Inmaculada Echevarría: implicaciones éticas y jurídicas", Medicina Intensiva, vol. 32, n 9 (2008) disponible en http:// scielo.isciii.es/scielo.php?pid=S0210-56912008000900005\&script=sci_arttext
} 
En Camino (2008) Javier Fesser cuenta la corta vida de Alexia González-Barros (1971-1985), la niña de familia del Opus Dei a quien diagnostican un tumor maligno del que fallece diez meses después, tras un doloroso tratamiento médico y que, debido a la aceptación espiritual de su sufrimiento, está en proceso de beatificación. La película describe hasta descarnadamente la evolución de la enfermedad, el deterioro del cuerpo y la incomprensible actitud de la madre de Alexia y de otros miembros del Opus que subliman el dolor y la muerte por la vía de ensalzarlos como queridos por la divinidad y, por tanto, vienen a hacer de la vida terrena un valle de lágrimas perverso y malvado. Contrasta esa actitud con la impotencia callada del padre de Alexia. El resultado es una crítica a una educación religiosa manipuladora de las conciencias más débiles; se pone en cuestión la concepción del catolicismo hecha de resignación y voluntarismo, de enaltecimiento del sacrificio y el dolor, de una comprensión del amor de Dios y de sus designios que linda con el fanatismo. La institución del Opus Dei había sido objeto de crítica por su oscurantismo en El código Da Vinci (The Da Vinci Code, Ron Howard, 2006), adaptación de un fantasioso best-seller de nulo valor literario que alcanza los 50 millones de ejemplares vendidos; de ahí que reacciona frente a Camino con el documental Alexia (Pedro Eugenio Delgado, 2011) ${ }^{21}$ y frente a otras críticas con la hagiografía de su fundador en Encontrarás dragones (There be dragons, Roland Joffé, 2011), ambientada durante la Guerra Civil en buena parte de su metraje.

En el caso de Al final de la escapada (Albert Solé, 2010), la evocación de la vida del militante comunista Miguel Núñez González (1920-2008), desde su labor como comisario político en la guerra hasta los años de cárcel y la clandestinidad durante el franquismo, sirve en gran medida para una defensa del derecho a la muerte digna. En la primavera del 2008 y después del llamado "caso Leganés", en que la Consejería de Sanidad de la Comunidad de Madrid acusó a varios médicos del Hospital Severo Ochoa de "asesinato" por practicar sedaciones paliativas, con un enfisema pulmonar, a sus 87 años Miguel temía el sufrimiento y decidió trasladarse a Barcelona en busca de especialistas favorables a la llamada "muerte digna". Desde una funcional residencia geriátrica logró citas con importantes personalidades del mundo de la política, entrevistas con periodistas, visitas de asociaciones pro eutanasia, interpelaciones con médicos amigos y el apoyo incondicional de su familia... ${ }^{22}$

\section{Conclusiones}

1. Lejos de haber sido cerrada con el ciclo dedicado por el cine español en 1976-1984, la reflexión e interpretación de la Historia del España del siglo XX y del franquismo en particular, conoce en la primera década de la siguiente centuria un nuevo ciclo,

21 Es un documental de entrevistas con Alexia y Hugo, su ángel de la guardia, como protagonistas. Hay abundante documentación en la web www.alexialapelicula.com. El director de hace eco de que "Hablé con los médicos y también con un demonólogo y exorcista, José Antonio Fortea, que confirman que [Alexia] sufrió tres casos de acoso diabólico (sic) durante los últimos días de su vida" ABC-Sevilla, 12-5-2011).

22 Hay intervenciones de Marcos Ana, Agustín Ibarrola, Pasqual Maragall, Evo Morales, Ernesto Cardenal y Sebastià Piera. 
esta vez centrado más en figuras concretas que en episodios o sucesos históricos. Ello responde al clima de vindicación de los valores y la cultura democráticos subyacente a la Memoria Histórica de ese momento.

2. Las biografías fílmicas de personajes históricos pertenecen a formatos muy variados y poseen tratamientos de distinta naturaleza, pero en gran parte vienen claramente motivadas por la reivindicación, el homenaje o el deseo de difundir la figura histórica en orden al conocimiento y reconocimiento. Esta perspectiva explica que en algunos casos la biografía se reduzca a una época muy precisa -en La buena nueva los tres años de la guerra- o a los episodios que han otorgado dimensión pública al personaje; incluso se vertebra el retrato de un personaje a través de un episodio histórico de escasa relación con él, como en Llach, la revolta permanent.

3. En varios títulos la condición de biografía queda relegada a un segundo plano frente al interés en abordar un tema polémico de forma comprometida (Mar adentro, Al final de la escapada), desarrollar una alegoría con valor ejemplificador (Ágora, Camino) o plasmar el contexto histórico político (La muerte de nadie). En este sentido, estas biografías fílmicas poseen casi siempre un trasfondo ético, político, historiográfico... que trasciende la trayectoria concreta del personaje retratado y por el cual se implica al ciudadano en el pasado histórico (Liste, pronunciado Lister), se subrayan mecanismos de poder de países dominantes (El misterio Galíndez), se caricaturiza el clima de miseria moral y política de una sociedad (;Buen viaje, Excelencia!), se denuncian las violaciones de derechos humanos (Salvador, La vida de nadie) o se evidencia la dinámica criminal del nacionalismo armado (Yoyes).

4. La yuxtaposición entre imágenes documentales y otras de ficción, y los mecanismos de enunciación del cine en el cine o de teatro en el cine o de narrador en el cine... por los que se establecen dos niveles narrativos en el relato (Azaña, El coronel Macià, Liste, pronunciado Lister, El misterio Galíndez, Buenaventura Durruti, ;Buen viaje, Excelencia!, Che, el argentino, etc.) sirven como medio de articulación entre ficción y no ficción, pues la totalidad de la película viene a presentarse como un documental sobre una ficción o una ficción sobre unos hechos documentales (El misterio Galín$d e z$ ), se establece una interpretación del pasado a la luz de determinadas ideas del personaje (Che, el argentino) o se lleva a cabo un ensayo donde pasado y presente entran en diálogo (Liste, pronunciado Líster). Ello explicita la autoconciencia del texto fílmico y la condición de discurso acerca de sucesos históricos, a diferencia de la ilusión con que opera el cine histórico clásico cuyas obras se presentan como la representación inmediata y fiel de esos sucesos. Este tipo de enunciación aparece en otros filmes de recreación histórica, como Soldados de Salamina (David Trueba, 2003), que traslada a la pantalla el mismo metalenguaje de la novela homónima. En los casos de Liste, pronunciado Lister, Buenaventura Durruti, Caracremada, ;Buen viaje, Excelencia! la heterogeneidad de materiales y procedimientos rompe claramente con los formatos habituales de documental y ficción, por lo que habría que hablar de ensayos biográficos audiovisuales para referirse a estas películas.

5. En algunos casos (Garbo, El honor de las injurias, Salvador, La muerte de nadie) fragmentos de películas de ficción sirven para ilustrar relatos con voz en off de hechos 
reales, de suerte que la ficción funciona como aval o confirmación del testimonio oral. Un ejemplo curioso son las imágenes de la película de ficción Operación Ogro (Gillo Pontecorvo, 1979) que recrean el atentado al almirante Carrero Blanco y que se utilizan, entre otras, en Salvador, ;Buen viaje, Excelencia! y La muerte de nadie como visualización de los hechos de la narración oral. Ello otorga al cine de ficción un estatuto ambiguo en cuanto puede suponer un aval pseudodocumental de los hechos históricos, aunque más bien habría que pensar en una novedosa función del cine difundido como garante de la veracidad de otras películas.

6. La presencia de las biografías de líderes políticos latinoamericanos en el cine español, sin conexión con la historia de España, se explica por las políticas de coproducción con las cinematografías trasatlánticas, pero también por la empatía con figuras muy admiradas; de hecho, las películas citadas participan del modelo de biopic considerado como "vidas ejemplares".

\section{Bibliografía}

ALONSO GUTIÉRREZ, Juan Manuel (2010): "Los militares en cinco biopics de la democracia", Actas del II Congreso Internacional Historia y Cine: la biografia filmica, Universidad Carlos III de Madrid, disponible en http://e-archivo.uc3m.es/ handle/10016/11295

ALTMAN, Rick (2000): Los géneros cinematográficos, Barcelona, Paidós.

BINGHAM, Dennis (2010): Whose Lives Are They Anyway? The Biopic as Contemporary Film Genre, Piscataway (New Jersey), Rutger University Press.

BURDIEL, Isabel (2000): «La dama de blanco: notas sobre la biografía histórica», en Burdiel, Isabel y Pérez Ledesma, Manuel (coords.), Liberales, agitadores y conspiradores. Biografias heterodoxas del siglo XIX, Espasa-Calpe, Madrid, pp. 17-47.

CUSTEN, George F. (1992): Bio/Pics: How Hollyvood Constructed Public History, Piscataway (New Jersey), Rutger University Press.

MORAL, Javier (2010): "La rehabilitación del vencido: cine biográfico y memoria histórica", Actas del X Congreso de la Asociación de Historia Contemporánea: Nuevos horizontes del pasado. Culturas políticas, identidades y formas de representación, Santander, 2010, disponible en www.ahistcon.org

MORALES MOYA, Antonio (1994): "Formas narrativas e historiografía española", Ayer, ISSN 1134-2277, $\mathrm{n}^{\circ}$ 14, pp. 13-32

PABLO, Santiago de (2001): "Introducción. Cine e Historia: ¿La gran ilusión o la amenaza fantasma?", Revista de Historia Contemporánea (Universidad del País Vasco) núm. 22, pp. 9-28. ISSN 1130-2402

SÁNCHEZ NORIEGA, José Luis (2004a): Diccionario temático del cine, Madrid, Cátedra.

-- (2004b): "Momentos significativos del cine histórico español. Hipótesis de trabajo sobre Cine e Historia", en ALFONSO DEL AMO y otros, Apuntes sobre las rela- 
ciones entre el cine y la historia (El caso español), Salamanca, Junta de Castilla y León, 2004, pp. 111-122.

SECO SERRANO, Carlos (1989): Haciendo historia: homenaje al profesor Carlos Seco, Madrid, Editorial Universidad Complutense.

SIMÓN-LORDA, Pablo e BARRIO-CANTALEJO, Inés María: "El caso de Inmaculada Echevarría: implicaciones éticas y jurídicas", Medicina Intensiva, vol. 32, $\mathrm{n}^{\mathrm{o}} 9$ (2008) disponible en http://scielo.isciii.es/scielo.php?pid=S0210$56912008000900005 \&$ script $=$ sci_arttext

VEIGA ALONSO, Xosé Ramón (1996): "Biografía y conocimiento histórico. El caso del conde de Pallarés", Revista de Historia Contemporánea (Universidad del País Vasco) ISSN 1130-2402, núm. 13-14, pp. 341-349. 